\title{
NR3C2 wt Allele
}

National Cancer Institute

\section{Source}

National Cancer Institute. NR3C2 wt Allele. NCI Thesaurus. Code C51706.

Human NR3C2 wild-type allele is located in the vicinity of 4 q31.1 and is approximately 364 $\mathrm{kb}$ in length. This allele, which encodes mineralocorticoid receptor protein, plays a role in transcriptional regulation and subsequent gene expression. 